ACRL SUBJECT SPECIALISTS SECTION AGRICULTURE AND BIOLOGICAL SCIENCES SUBSECTION

Bruef of Minutes

January 30, 1969

Present: Louise Darling, Chairman; Howard Rovelstad, Vice-Chairman (Chairman Elect); Thomas Gillies, Chairman, Subject Specialists Section; Richard T. Samuelson, Member, 1969/70 Nominating Committee; Anna E. Dougherty, Secretary. Pauline W. Jennings, Immediate Past Chairman was unable to attend due to a death in the family.

The Agriculture and Biological Sciences Subsection Executive Committee held its Midwinter meeting on Thursday, January 30, 1969 , from 4:30 until 6:00 p.m. in Club Room C of the Shorcham Hotel in Washington, D.C.

The Chairman expressed her pleasure in having Mr. Gillies, Section Chairman, present at the meeting. Mr. Samuelson gave the report of the 1969/70 Nominating Committee. 'The Chairman reported for the Oberly Award Committee since Mr. Fleming Bennett, Committee Chairman, had to leave the Midwinter
Meeting early. It is possible that no award will be given this year due to the lack so far of impressive candidates. If an award is given, it will be presented on June 25 at the Program meeting in Atlantic City.

The Atlantic City meeting will be a joint meeting of the Section and the Subsection. It was decided that the Section business meeting should be held first. Then the Subsection business meeting, and Award if given, will take place prior to the Program meeting. Discussion followed concerning the estimated attendance in order to arrange for a meeting room. It was agreed that advance notification of the meeting would appear in the ACRL News and that flyers would be mailed to the entire Section membership. Announcements would be sent to the Bulletin MLA, Special Libraries and possibly to AHIL.

Louise Darling indicated that Mr. John Sherrod, Director of the National Agricultural Library, who will be the speaker at the Atlantic City Joint meeting will be invited to have cocktails informally with the Subsection Executive Committee and the chairmen of the two Committees after the joint meeting. She will try to set the Subsection Executive Committee for Thursday May 26 at 4:30 p.m. Various projects were discussed as not

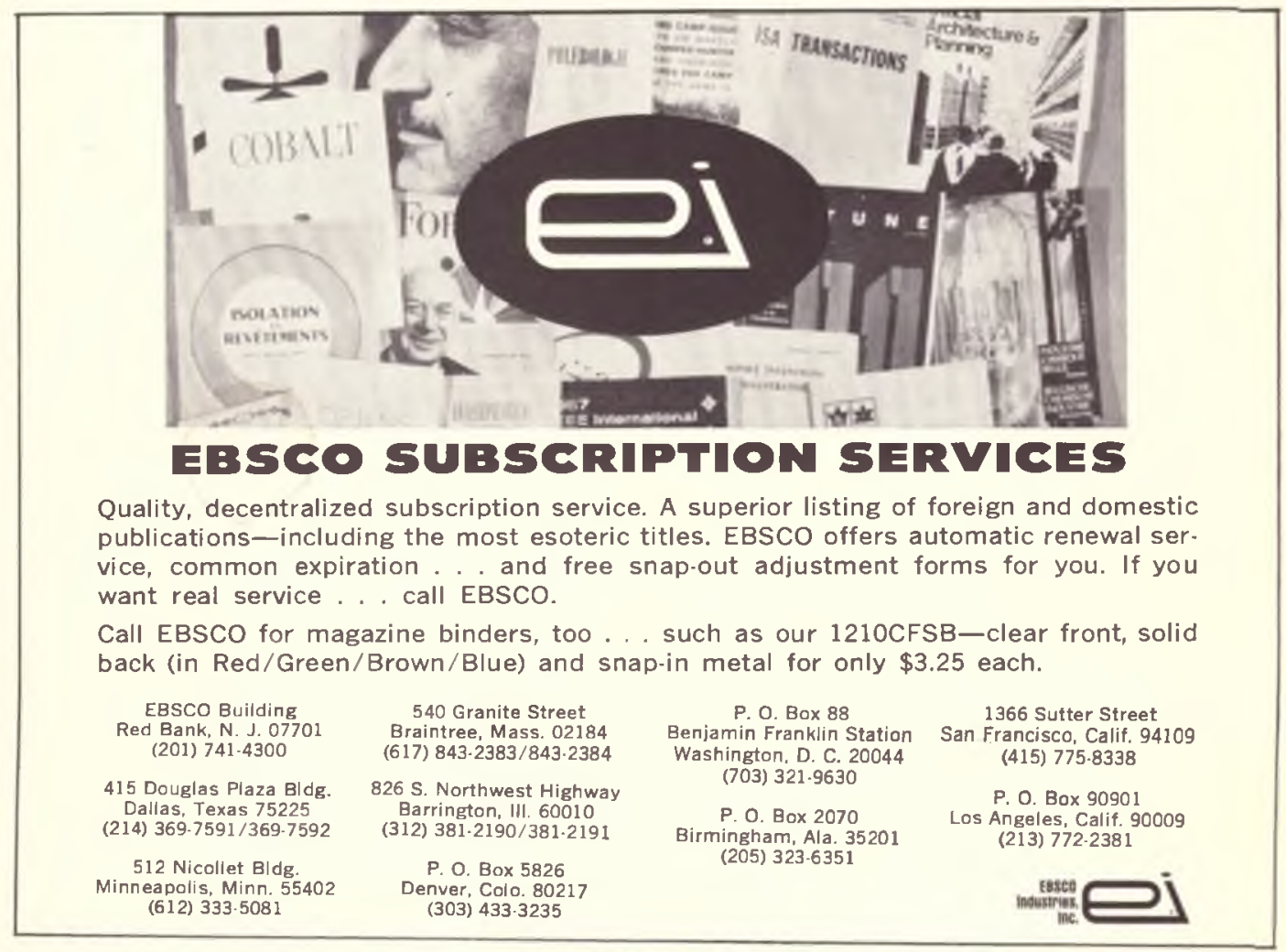


profitable to be undertaken by the Subsection at this time. The nominal $\$ 50.00$ will then be received for the $1969 / 70$ budget.

Harold Rovelstad discussed names of persons to serve as Chairman of the Subsection Nominating Committee for $1970 / 71$ and for the Oberly Award Committee.

The meeting was adjourned at 6:00 p.m.

\section{ACRL SSS AD HOC BYLAWS COMMITTEE APPOINTED}

The purpose of the Committee, which has been at work and which has made its first report to the Executive Committee of SSS at the Midwinter meeting in Washington, is to appraise the present Bylaws of the Subject Specialists Section for possible conflict with the Constitution and Bylaws of ACRL. They will make a second report to the Executive Committee at the Atlantic City meeting in June, and probably a report to the membership at a future meeting. Membership of the Committee is as follows:

Miss Marcia J. Miller, U.S. Department of Labor Library, Chairman

Miss Mary E. Schell, California State Library Mr. Jerzey (George) Maciuszko, John G. White Department, Cleveland Public Library.

\section{LIBRARY UNIONIZATION STUDY}

Professor Archie Kleingartner and Ted Guyton of the Graduate School of Business Administration, University of California, Los Angeles, are currently gathering information for an extensive study of unionization and collective bargaining among professional librarians. Because of the dearth of published materials available on this topic, they would be deeply grateful to hear from any person directly involved in library union activity or who has information on the topic. It is planned that the study will result in a monograph length history of the topic which will be of interest both to students of labor and to professional librarians. All inquiries and correspondence may be addressed to Archie Kleingartner, Assistant Professor of Industrial Relations, Graduate School of Business Administration, University of California, Los Angeles, California 90024.

\begin{tabular}{|c|c|}
\hline \multicolumn{2}{|l|}{ ACRL Membership } \\
\hline March 31, 1969 & 11,776 \\
\hline March 31, 1968 & 11,464 \\
\hline March 31, 1967 & 10,690 \\
\hline March 31, 1966 & 9,313 \\
\hline
\end{tabular}

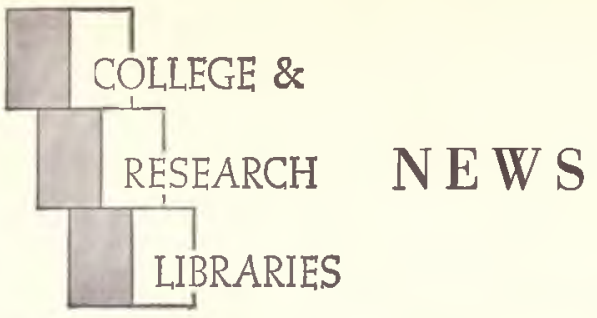

ACRL News Issue of College \& Research Libraries

Editor, David Kaser, Cornell University Libraries, Ithaca, N.Y. 14850.

Managing Editor, Mary Falvey, 50 E. Huron St., Chicago 60611.

News Editor, David Doerrer, CornelI University Libraries, Ithaca, N.Y. 14850.

Editorial Board: Jorn M. DAwson, University of Delaware; Gustave A. Harren, University of Florida; Samoel Rothstein, University of British Columbia; James E. Skipper, University of California, Berkeley; Nonman E. Tanis, Kansas State College of Pittsburg; Maunice F. Tauber, Columbia University; EmeEN Thornton, Oberlin College.

ACRL Officers, 1968/69: President, David Kaser; Chairman, College Libraries Section, Evan Ira Farber; Junior College Libraries Section, Shirley A. Edsall; Rare Books Section, J. M. Edelstein; Subject Specialists Section, Thomas D. Gillies; Agriculture and Biological Sciences Subsection, Louise Darling; Art Subsection, Herbert G. Scherer; Law and Political Science Subsection, Morris L. Cohen; Slavic and East European Subsection, Dmytro M. Shtohryn; University Libraries Section, G. F. Shepherd.

News from the Field, Personnel profiles and notes, classified advertising, official matter of ACRL, and other material of a timely nature is published in the News issues of College \& Research Libraries.

Inclusion of an article or advertisement in $C R L$ does not constitute official endorsement by ACRL or ALA.

Production and Advertising and Circulation office: 50 E. Huron St., Chicago, Ill. 60611. Change of address and orders for subscriptions should be addressed to College \& Research Libraries, for receipt at the above address, at least two months before the publication date of the effective issue.

Subscription to $C R L$ is included in membership dues to ACRL of $\$ 6$ or more; other subscriptions to $C R L$ are $\$ 10$ per year. Neither subscriptions nor memberships include miscellaneous unscheduled supplements, which are available by purchase only. Retroactive subscriptions are not accepted. Single journal copies are available at $\$ 1.50$ each and News issues at $\$ 1.00$ each from ALA Publishing Department.

Indexed in Library Literature. Abstracted in Library Science Abstracts. Book reviews indexed in Book Review Index.

College of Research Libraries is the official journal of the Association of College and Research Libraries, a division of the American Library Association; and is publisbed seventeen times per year-bi-monthly as a technical journal with 11 monthly News issues, combining July-August-at 1201-05 Bluff St., Fulton, Mo. 65251.

Second-class postage paid at Fulton, Mo. 